\title{
Sanatın Doğasına Yönelik Bir Sorgulama: "Yargı Yetisinin Eleştirisi" ve "Shi (Poetry)"1
}

\author{
Tezcan Kaplan \\ Araştırma Görevlis \\ Ankara Hacı Bayram Veli Üniversitesi \\ İletişim Fakültesi \\ tezcankaplan@gmail.com \\ ORCID: 0000-0003-2907-7530
}

\section{Abstract \\ An Inquiry Into the Nature of Art: "The Critique of Judgement" and "Shi (Poetry)"}

The fundamental problem of this study is to know how to establish the direct relation between beauty and the art in which beauty is spontaneously implanted. This relationship can only be established on a theoretical basis. Beauty works on this theoretical ground with other concepts (taste, form, etc.) to which we refer to define art. This conceptual wholeness creates an aesthetic plane and connects to other planes such as ethics. The ethical plane divides this wholeness into itself; aesthetics become functional from an ethical point of view. Beauty and Good go hand in hand. The Kantian aesthetic offers the theoretical ground on which we can analyze these connections. The objective of this study is to analyze the film "Shi (Poetry)" by Chang-dong Lee, a renowned director of South Korean cinema, in terms of Kantian aesthetics. The hermeneutical method was chosen in order to show how the film corresponds to the Kantian perspective by focusing on the chapter "Critique of the faculty of aesthetic judgment" of Kant's work "Critique of the faculty of judgment". Another axis of the study concerns Mija, the main character of the film, who tries to write a poem. This is the reason why the film is chosen as the object of analysis because it reveals certain issues regarding the nature of art as a result of this effort. From the moment Mija begins to try to write a poem, evils begin to surround her and therefore poetry becomes not only a means of expression of beauty, but also a moral shelter where she protects

1 Sinefilozofi Dergisi, 1. Ulusal Sinema ve Felsefe Sempozyumu'nda, 23-25 Kasım 2018'de sunulmuş bildirinin geliştirilmiş halidir.

DOI:10.16878/gsuilet.957457 
herself from evil. The moral level that she reaches with poetry, she also arrives there through ethical action. This action will be treated within the framework of Kant's reflections on the Sublime. The main conclusion of this study is that the film has narrative elements in which the fundamental concepts of Kantian aesthetics such as taste, art, genius and the Sublime crystallize.

keywords: Kant, art, beautiful, sublime, Shi movie

\section{Résumé}

\section{Une interrogation sur la nature de l'art : " Critique de la faculté du jugement " et " Shi " (Poésie)}

La problématique fondamentale de cette étude est de savoir comment établir la relation directe entre la beauté et l'art dans lequel la beauté s'implante spontanément. Cette relation ne peut être établie que sur une base théorique. La beauté fonctionne sur ce terrain théorique avec d'autres concepts (goût, forme, etc.) auxquels nous nous référons pour définir l'art. Cette intégralité conceptuelle crée un plan esthétique et se connecte à d'autres plans tels que l'éthique. Le plan éthique fait une répartition de cette intégralité en soi ; l'esthétique devient fonctionnelle par rapport au plan éthique. La Beauté et le Bien vont de pair. L'esthétique kantienne offre le terrain théorique sur lequel nous pouvons analyser ces connexions. L'objectif de cette étude est d'analyser le film "Shi (Poésie) " de Chang-dong Lee, un réalisateur renommé du cinéma sud-coréen, en termes d'esthétique kantienne. La méthode herméneutique fut choisie afin de montrer à quel point le film correspond à la perspective kantienne en se focalisant sur le chapitre "Critique de la faculté du jugement esthétique " de l'œuvre "Critique de la faculté du jugement "de Kant. Un autre axe de l'étude porte sur Mija, le personnage principal du film, qui s'efforce d'écrire un poème. C'est la raison pour laquelle le film est choisi en tant qu'objet d'analyse car il révèle certains problèmes concernant la nature de l'art à la suite de cet effort. À partir du moment où Mija commence à essayer d'écrire un poème, les maux commencent à l'entourer et la poésie ne devient donc pas seulement un moyen d'expression de la beauté, mais aussi un abri moral où elle se protège du mal. Le niveau moral qu'elle atteint avec la poésie, elle y arrive également à travers une action éthique. Cette action sera traitée dans le cadre des réflexions de Kant sur le Sublime. La principale conclusion de cette étude est que le film comporte des éléments narratifs dans lesquels se cristallisent les concepts fondamentaux de l'esthétique kantienne tels que le goût, l'art, le génie et le Sublime.

mots-clés: Kant, art, beau, sublime, le film Shi 


\section{Öz}

Bu çalışmanın temel sorunsalı, sanat alanına kendiliğinden gelip yerleşen güzelin-güzelliğin sanatla olan bu dolaysız ilişkisinin nasıl kurulabileceğidir. Bu ilişki ancak teorik bir zemin üzerinde kurulur. Güzel, bu teorik zeminde, sanatı tanımlarken başvurduğumuz diğer kavramlarla (beğeni, biçim vb.) birlikte çalışır. Bu kavramsal bütünlük, estetik bir düzlem oluşturur ve etik gibi diğer düzlemlere bağlanır. Etik düzlem, bu bütünlügü kendi içinde yeniden dağıtır; estetik, etik düzleme göre işlevselleşir. Güzel ve lyi yan yana gelir. Kant estetiği, bu bağlantıları çözümleyebileceğimiz teorik zemini sunar. Bu çalışma, bu zemine bir film aracılığıyla yerleşmiştir. Çalışmada, son zamanlarda adından sıklıkla söz ettiren Güney Kore sinemasının önemli yönetmenlerinden biri olan Chang-dong Lee'nin Shi (Poetry) adlı filminin, Kant'ın estetiğe dair görüşleri açısından çözümlenmesi amaçlanmıştır. Filmin Kantçı perspektifle ne ölçüde örtüştügü yorumsamacı (hermenötik) yöntemle belirlenecektir. Bu bağlamda, Kant'ın Yargı Yetisinin Eleştirisi adlı eserinin "Estetik Yargı Yetisinin Eleştirisi" adlı bölümüne odaklanılmıştır. Çaıışmanın diğer bir ayağını oluşturan Shi (Poetry) filminin ana karakteri olan Mija ise, bir şiir yazma çabası içerisindedir. Filmin örneklem olarak belirlenme nedeni de, bu çabanın sonucu olarak sanatın doğasına yönelik bazı problemler ortaya koymasıdır. Bu problemlere Kant estetiği açısından karşııklar bulmak, çalışmanın temel motivasyonunu oluşturmuştur. Mija şiir yazmaya çalışırken etrafındaki kötülükler onu kuşatmaya başlayacak ve şiir, onun için artık sadece güzelin bir ifadesi değil bu kötülüklerden korunacağı ahlaki bir sığınak olacaktır. Şiirle ulaştığı ahlaki boyuta, aynı zamanda etik bir eylemle de ulaşacaktır. Bu eylem, Kant'ın Yüce'ye dair görüşleri çerçevesinde ele alınacaktır. Çalışmanın ulaştı̆̆ı temel sonuç filmin, Kantçı estetiğin temel kavramları olan beğeni, sanat, deha ve Yüce gibi kavramların billurlaştığı anlatı öğelerine sahip olduğu yönündedir.

anahtar kelimeler: Kant, sanat, güzel, yüce, Shi filmi 


\section{Giriş}

Kant felsefesi için söylenebilecek temel şeylerden biri, aklın sıkı ve sistematik bir şekilde eleştiriden geçirilmesidir. Bu eleştirinin ana motivasyonunu ise, insan aklının kayıtsız kalamayacağı diyalektik akıl yürütmeler oluşturur. Aklın diyalektik işleyişinin kaçınılmaz sonucu olarak bu akıl yürütmelerin metafizik ile ilişkisindeki açık edilişi, saf aklın bilgilerinden pratik aklın yasalarına kadar uzanan bir hat içerisinde sistematik bir bütünlük sergilemektedir. Bu hattın son ve belki de en önemli tuğlası olarak öne çıkan yargı yetisinin eleştirisi, yapının bütünlüğü için bir harç görevi görür gibidir, "iki ayrı alanı (doğa ve akıl dünyası), insanın varlık bütününde bir araya getirmektedir" (Heimsoeth, 2016, s. 144). Altuğ'un da belirttiği gibi, "akıl ilkeleri; anlama yetisi nesneleri verirken; yargı gücü, ilkeleri nesnelere uygulama görevini yerine getirmektedir" (Altuğ, 2007, s. 20).

Yargı yetisi, akın yetileri arasındaki işleyişi sağlar. Kant, bu yetinin hiçbir deney unsurunun karışmadığı a priori ilkelerini araştııır. Bu araştırmada, öncelikle, yargı yetisinin diğer iki bilme yetisinden, yani anlama yetisi ve akıldan farkı ortaya konur. Yargı yetisinin bağımsız ve ilkelerinin a priori olmasının en önemli koşulu, bu ilkelerin oluşturucu mu yoksa düzenleyici mi olduğunu, açıklayıcı (analitik) ve genişletici (sentetik) ayrımında hangi tarafta bulunduğunu belirlemektir (Kant, 2016, s. 23-24). Kant'ın metafiziği bir bilim olarak belirleme uğraşının temeli olan (saf matematik ve saf doğa bilimlerinde olduğu gibi) sentetik a priori ilkelerin keşfi, yargı yetisinin bağımsız bir yeti olması için de temel meseledir. Bu yetinin belirlenimi refleksiyonlu düşünmedir. Bu derin düşünme edimiyle yargı yetisi, mantıksal neden sonuç zinciri dışında, belirleyici ve açıklayıcı niteliklerinden farklı bir nitelik sergiler.

Yargı yetisinin a priori ilkeleri hoşlanma ya da hoşlanmama duygusuyla dolaysız bir bağıntı içerir. Bu duygu vurgusu, yargı yetisinin kavramlara sığmayan niteliğinin yanı sıra temel olarak öznede yer aldığının göstergesidir. Aynı zamanda, anlama ve arzulama yetisi arasında oluşan paradoksal yapısının temel bloğunu oluşturur. Kant, yargı yetisinin estetik doğasını belirginleştirmek adına, öncelikle, onu anlama yetisindeki işlevinden ayırır. Bu kullanımında yargı yetisi belirleyicidir ve olumsal olan tikeli, verili bir evrenselin veya kavramın altına koyar. Yargı yetisinin özerk alanını ise derin düşünüm gücü oluşturur. Verili olan tikeli ifade edecek belirsiz evrenseli bulmaya çalışır. Doğadaki ve sanattaki güzel bu düşünüm gücünün eseridir.

Shi (Poetry) filmi, Kant'ın estetik için açtığı bu bağlam içinde değerlendirilecektir. Doğa ve sanat ilişkisinin nasıl ele alındığı, film evrenindeki karşı-bağlamlarla açıklanacaktır. Bu açıklama girişiminde, yorumsamacı yöntem kullanıımıştır. Filmin "bir bütün olarak sunduğu bakış açısını özümsemeye ya da onun içine girmeye ve sonra parçalarının bütünle nasıl ilişkilendiğine dair" (Neuman, 2012, s. 130-131) bir anlayış geliştirilerek, içindeki yerleşik anlam, betimleyici bir tavırla açık edilmeye çalışılmıştır. Filmin bütününe sirayet eden bakış açısı ise, sanatın 
teorik ve pratik alanla kurduğu gerilimli ilişkidir. Bu yöntem aracılığıyla, çalışmanın temel problemi de olan bu gerilimli ilişkinin kavramsal haritasını çıkararak, filmin sunduğu anlatı öğelerinin bu haritaya karşılık gelen bölgelere göre analiz edilmesi amaçlanmıştır. Bu amaca göre alt amaçları şu şekilde sıralayabiliriz: filmdeki anlatı öğelerinden hareketle Kantçı anlamda güzeli tanımlamak, güzelin iyiyle-kötüyle ve doğruyla olan ilişkisini açık etmek ve sanat ve yaşam arasında bir bağlantı oluşturmak. Filmi çalışma açısından özgün kılan nitelik ise, bu amaç ve alt amaçları gerçekleştirebileceğimiz bağlamlar sunmasıdır. Kant'ın estetik görüşlerini ayrı bir başlık altında toplamak yerine, Kantçı estetiğin genel hatları, bu bağlamlarla birlikte ele alınmıştır.

\section{Literatür Özeti}

Film çalışmalarını kabaca iki kısma ayırabiliriz: sinemaya kuramsal olarak yaklaşma ve filmleri kuramlar aracılığıyla açıklama. Ilık kısmı da ikiye ayırabiliriz. Birinci alt kümede tür, anlatı, biçim, montaj gibi sinemanın teknik konularına eğilen çalışmalar, ikinci alt kümede ise, sinemanın bu teknik unsurlarla taşıdığı düşünce potansiyelini öne çıkaran çalışmalar yer alır. Fakat bu iki alt küme, birbirinden net bir şekilde ayrılamaz. Örneğin, Deleuze, imge ve göstergeleri sınıflandırmadan önce sinemanın teknik unsurlarını açıklamıştır. Film çalışmalarındaki ikinci kısma göre de açıklamalar yapar. Örneğin, duygulanım imgede "herhangi bir mekân" kavramını açıklarken inanç ve seçim ilişkisini varoluşçu felsefe üzerinden ele alır (Deleuze, 2001, s. 114-117). Örnekleri çoğaltmak mümkündür. Söz gelimi, Bazin montaja ve alan derinliğine odaklanarak veya Kracauer sinemanın fotoğraftan ayrımını ortaya koyarak sinema kuramlarını geliştirmişlerdir.

Film çalışmalarında ağırlık merkezini filmleri kuramlar aracılığıyla açıklama oluşturur. Bu zorunlu olarak böyledir çünkü ister sinemada geliştirilen bir kuram olsun, isterse kuramlar filmlerin üstüne biçilmiş olsun, kuram ve sinema arasında bir tatbik ilişkisi vardır. Fakat bu değer açısından ikisinin de aynı olduğu anlamına gelmez. Özellikle, felsefenin olanaklarıyla sinemaya yaklaşmak film çalışmaları açısından verimli bir alan açar. Ulusal akademik yazında bu alanın ciddi bir şekilde dikkate alındığını savunabiliriz. Örneğin, ülkemizde Metin Gönen, Hakan Savaş, Özcan Yılmaz Sütçü ve Serdar Öztürk ilk akla gelen isimlerdir.

Bu çalışma özelinde ise, ulusal literatürde üç çalışma tespit edilmiştir. Birincisi, Güven Özdoyran'ın “Medya Çalışmalarında Geriye Dönük Yeniden Okumalar: (Deleuze Sonrası) Kant ve Film" adlı makalesidir. Özdoyran bu makalesinde, Kant'tan hareketle Deleuze'ün öne sürdügü zaman anlayışının film izleme deneyimine dair yeni ufuklar açtığını savunur. Bu çalışmayı yukarıda yaptığımız ayrımın ilk kısmına dâhil edebiliriz. Diğer iki çalışmayı ise ikince kısma göre sınıflandırabiliriz. Özgür Yaren "Sinemasal Yüce: Felaket Filmlerinde Yüce Arayışı" adlı makalesinde, film izleme deneyimini Kant'ın Yüce kavramıyla felaket filmlerini ilişkilendirerek açıklar. Hatice Sevgi Zengin'in "Kış Uykusu'nu Kant ve Nietzsche Etiği Çerçevesinde Düşünmek" adlı makalesinde ise, Kış Uykusu filmi, Kant'ın 
ödev ahlakının Nietzsche'nin efendi/köle ahlakıyla karşılaştııımasıyla analiz edilmiştir. Çalışmamı da bu sınıf içerisinde değerlendirebiliriz. Kant ve sinema/filmler arasındaki ilişkiye odaklanan çalışmalar dışında, Shi (Poetry) filmiyle ilgili ulusal literatürde bir çalışma vardır. Hakan Savaş'ın "Sinemada ve Edebiyatta Şiirin Yüzü" adlı eserinin ilk yazısı bu film üzerinedir. Savaş bu yazısında, odağını şiire göre ayarlayarak filme bakmıştır. Bu bakışın gördüğü tabloya, bu çalışma, Kantçı bir perspektiften bakmaya çalışmıştır. Uluslararası literatürde ise bir çalışma bulunabilmiştir. Hyeryung Hwang'a ait olan "Peripheral Aesthetics after Modernism: South Korean Neo-realism and Chang-dong Lee's Poetry" adlı çalışmada, film, batı modernist estetiğe karşı etik bir program olarak kabul edilen realist tavrın sona ermediğini gösteren yeni-gerçekçi bir eser olarak ele alınmıştır. Bu etik-estetik ilişkiyi, tarihsel bir gelişime veya Batı-Doğu ikiliğine göre değil, Kant estetiği içerisinde kalarak açıklamak bu çalışmanın temel amacıdır.

\section{Shi (Poetry) Filminin Kant'ın Estetik Görüşleri Çerçevesinde İncelenmesi}

Film iki hat üzerinden ilerler. Birinci hattı kabaca kötülük olarak ifade edebiliriz. Filmin ana karakteri olan Mija'nın (Jeong-hie Yun) torunu (Lee Da-wit) ve onun arkadaşları, okullarındaki bir kıza tecavüz etmişler ve onun intiharına neden olmuşlardır. İntiharın nedeni örtbas edilmeye çalışıır. Mija bu kötülükten kaçmaya çalışırken bir şiir yazma umuduna sığınır. Fakat hafızanın giderek zayıflamasına yol açan Alzheimer hastalığına sahiptir. Filmin ikinci hattını bu şiir yazma süreci oluşturur. Mija kötülüğün açtığı yaraları sanatla tedavi etmeye çalışır.

\section{Doğanın Güzelliği ve Sanatın Oyunu}

Film gürleyerek akan su sesiyle açılır, henüz ortada görsel malzeme yoktur. Filme işitsel öğeyle başlanması, görsel ve işitsel dengenin nasıl kurulduğunun da göstergesi olacaktır çünkü filme de adını veren şiir, sesin hesaba katılmasını gerektirir. Altuğ, Kant açısından şiirin sesle temel bir ilişkisi olduğunu savunur. Şiir, müzik ve ses tonu olarak da görülebilir veya "hoşa giden bir sese sahiptir" (Altuğ, 2007, s. 224). Kant, şiiri, ruhsal yetiler bütününü canlandıran bir söz sanatı olarak görür. Estetik ideleri sergilemesi açısından sanatlar arasında en yetkinidir. Bu canlandırıcı etkide işitsel bir öğe içermekte ve kendisini güzel bir ses olarak sunmaktadır (Kant, 2016, s. 125-135).

Filmin ilk görüntüsü, karanlıktan aydınlığa geçen bir nehirdir. Görsel ve işitsel unsurlar güzel bir harmonik manzara sunar. Ancak bu manzarayı bozacak bir kötülük resmedilecektir. Güzel manzaranın ardında her zaman kötü bir tablo belirecektir. Tüm karakterler kötülüğe bir biçimde bulaşacaktır.

Deleuze, Kant'la birlikte kötülük probleminin şekil değiştirdiğini savunur. Kant öncesi kötülük problemi, genellikle dışarıdan formüle edilir. Kötü olan maddedir veya bedendir. İyi olan ruh, maddeden gelen kötülüğe direnmelidir (Deleu- 
ze, 2015, s. 110). Kant ise, kötüyü dışarıya değil, içeriye yerleştirir. Akıl, ahlaki buyruk uyarınca içerideki kötülüğe karşı dikkatli olmalıdır². Kötülük filmdeki karakterlerin dışında değildir, karakterler kötülüğün içindedir veya her karakter kötülüğü kendi tarzında ortaya koyar.

Kötülüğün ilk tarzını, nehir kenarında oyun oynayan çocuklardan birisi fark eder. Filmde farklı öznelerle göreceğimiz oyun, filmin anlam dünyasını şekillendirir. Oyun metaforu güzele dair beğeni yargımızı açıklar. Kant, bu yargının oluşmasında imgelem ve anlama yetisi arasındaki oyunu kaçınılmaz görür. Beğeni yargısı, anlama yetisinin belirleyici yargısına değil, düşünücü yargı yetisine aittir. Bu nitelik şiir için de geçerlidir: "şair yalnızca idealarla eğlendirici bir oyun için söz verir ve gene de anlama yetisi üzerinde sanki amacı yalnızca yine işini yürütmekmiş gibi bir etki bırakır. Şiir sanatı imgelem yetisinin özgür bir oyununu anlama yetisinin bir işi gibi yerine getirme sanatıdır" (Kant, 2016, s. 130). Bu etkinlikte iki yeti, bilgi edinme açısından değil, özgür bir salınıma göre kendilerini karşııklı geliştirmeye ve sınırlarını genişletmeye yönelir (Schaper, 2005, s. 164). Tunalı'ya göre, iki yeti arasındaki bu oyun zaten bir beğeni veya estetik yargısıdır ve bu yargı ilgili nesneden, yani doğadan ve sanattan kaynaklanan hoşlanmadan önce gelir (Tunalı, 2017, s. 249). Ona göre, bu yargının evrensel olarak iletilebilmesinin koşulu da bu harmonidir çünkü oyun, akıl yetilerini harekete geçirmesi itibariyle, her öznede a priori olarak yer alır (Kant, 2016, s. 106). Deleuze, bu oyunu, "özgür ve belirlenimsiz bir uyum" olarak ifade eder. Bu oyunda imgelem yetisi, anlama yetisi ve akılda olduğu gibi yasa koymaz (Deleuze, 2009, s. 91). Sadece kendisine yasa koyabilir ve bu bağlamda ancak "heutonomous" olabilir (Kant, 2016, s. 28) ${ }^{3}$. Diğer iki yetinin yasa koyabilmelerinin koşulu, düşünücü yargı gücünün oluşturduğu bu uyum veya oyundur (Deleuze, 1995, s. 90-91). Bu uyum-oyununu, yetileri "tamamlama" işlevine göre değil, onların temeli olmasına göre kavramalıyız.

Film de bu temel üzerine kurulur. Oyun oynayan çocuklardan biri topraktan ayrılır ve nehre yönelir. O sırada bir kuş sesi duyar, bu güzel sesin kaynağını görmeye çalışır. Nehrin yüzeyinde toprağa yaklaşan küçük bir kız cesedi görür. Bu cesedin üstüne filmin ismi olan "Shi (Poetry)" yazısı bindirilir.

Bu açlış sahnesinden sonra, perdeyi kaplayan televizyonda bir anne çocuğu için ağlamakta ve isyan etmektedir. Mija'yı, hastanede bu televizyonu izlerken görürüz. Doktorun odasına gider ve şikâyetini anlatırken kullanması gereken kavramı unutur. Film ve Kant estetiği arasında bir düğ̈̈m daha örülür. Estetik deneyim, imgelem yetisinin özgür oyununu tamamlayacak anlama yetisinin belirli bir kavramından yoksunluk olarak ortaya çıkar. Duyulur dünyanın bilgisel deneyimi,

2 Baker, bu yer değişiminin toplumsal sonuçlarına dikkat çeker. Kötülüğün dışarıda olmaması, insanın yaşadığı ortamı kötülükten uzak tutar. Yaşamın modern-kapitalist nizamı, ortamın politik kurumlarca organize edilmesine neden olmuştur ve bu kurumlar, Foucault'nun da gösterdiği gibi, insanları yönetmenin araçlarına dönüşmüştür (2011, s. 54).

3 Kant, yargı yetisinin autonomous yapıda değil heutonomous yapıda olduğunu dile getirir. Yargı yetisi, fenomenler veya kendinde şeyler üzerine yasa koymaz, kendine yasa koyar. Yasasının nesnesi kendisidir. 
duyu verilerinin kavramlar altına koyulmasına dayanır: "duyusallık ve kavramlar öyleyse tüm bilgimizin öğelerini oluştururlar, öyle ki ne kavramlar belirli bir türde onlara karşılık düşen duyusallık olmaksızın, ne de duyusallık kavramlar olmaksızın bir bilgi verebilir" (Kant, 2017a, s. 77). Mija bu yetisini kaybetmeye başlar. Bu unutuş sayesinde yaşamı estetik formda deneyimleyecektir. Varoluşun bilgisel işleyişinden uzaklaşır ve karşılaştığı kötülüklere bir anlam veremez. Anlama yetisinin ilkesi olan nedenselliğin ve aklın ilkesi olan özgürlüğün arasındaki bir sınır bölgede yaşamaya çalışır. Doktor özellikle bu sınır bölgeye yaklaşmaya çalışır. Fakat Mija unutkanlığının ne zaman başladığını bile hatıllamaz ve hatta yaşını bile yanlış söyler.

Mija'nın düzenli bir işi yoktur, sadece yatalak bir adamın (Hee-ra Kim) bakımını yapar ve biraz da devlet yardımı alır. Bu iş için gitttiği yer, altı market üstü ev olan bir binadır. Bu marketin kasiyeri Mija'ya gülerek, «her zaman böyle süslü müsün ${ }^{4}$ diye sorar. Mija'ya göre kendisi süslü değildir, sadece güzel olmaya çalışır. Bir ressam gibi kendisini güzel nesnelerle biçimlendirir. Kant, resim sanatını biçimlendirici sanat grubuna dâhil eder ${ }^{5}$ ve öznenin kendisini ve etrafındaki nesneleri güzelleştirmesini bu sanat türüne göre değerlendirir: "geniş anlamda ressamlığın altına odaların duvar kâğıtları, takıntılar ve güzel mobilyalar ile süslenmesini de katıyorum ki, bunlar yalnızca bakılmaya yararlar ve beğeniye uygun giyinme sanatı için de aynı şeyler söylenebilir" (Kant, 2016, s. 132). Buradaki yarar vurgusu, hoş olana dayalı hazla ilişkili değildir ${ }^{6}$. Mija kendisini boş bir tuval gibi görür ve bu tuvali güzel bir özne haline getirmeye çalışır.

\section{Öğretilebilir Bir Forma Sahip Olmayan Sanat: Deha ve Estetik Deneyim}

Mija otobüs durağındaki şiir kursu ilanını görür. Kursun tarihi geçmiştir; belki onu daha önce de görmüştür ve diğer şeyler gibi unutmuştur. Eve gelir ve torununun anne karnındaki bir cenin gibi uzandığını görür. Mija, okulunda intihar eden kızı sorar ama o, yemeğine devam eder ve tanımadığını ifade eder. Akşam olur ve birlikte oyun oynarlar. Oyunla başlayan film, oyunla açılmaya devam eder. Torunu birden oyunu bırakır çünkü bir telefon gelir ve arkadaşları onu çağııır. Kim bilir belki de, suçun ortağı olan çocuklar, nasıl kurtuluruz diye konuşacaklardır veya oyun oynayacaklardır...

4 Filmden alınan diyaloglar ve Mija'nın aldığı notlar, süre aralıkları belirtilerek metin boyunca verilecektir: 00:12:16.

5 Kant sanat eserlerini, estetik idelerin ifade tarzına göre üçe ayırır: konuşma sanatı (retorik ve şiir), biçimlendirici sanat (plastik ve resim) ve duyumların oyununun sanatı (müzik ve renk) (2016, s. 129-133).

6 Kant, estetik deneyimin öznede temellenen yapısının ilgiden bağımsızlı̆ını göstermek için, öncelikle, onu hoş olana dayalı hazdan ayırmaya çalışır. Her iki hazzın koşulu duyuların alıcılığıdır. Ancak hoş olana dayalı hazda, nesnenin varoluşuna yönelik bir ilgi söz konusudur. Araç-amaç bağlantısına göre belli bir doyumun nesnesi yapılır. Bir nesnenin güzel bulunmasındaki hazda ise, kavramsal bir müdahale olmadan nesnenin ne ise o olmaklığı duyumsanır. Bu duyumsamada nesne, bir arzuyu gidermenin aracı değildir. Belli bir estetik mesafe sayesinde, yetilerin özgür oyununa yer açan düşünüm gerçekleşir (2016, s. 40-42). 
Mija şiir kursuna kabul edilmiştir ve şiir "öğretmeni" (Yong-taek Kim), şiir yazmanın en önemli dersini verir: görmek. Nesneleri araç-amaç bağlamından çıkararak doğrudan görmek ve onları biçimleriyle imgelem yetisinde tasarlamak, Kant estetiğinin temel özellikleridir. Kant estetiğinde biçim, "bir nesnenin, imgelem yetisinin düşünümsel olarak yansıttığı yönüdür ve biçim, nesne mevcut olduğu ve bize etkide bulunduğu ölçüde bu nesnenin bizde uyandırdığı duyumların maddi öğesinden ayrılır" (Deleuze, 1995, s. 88). Estetik deneyimde özne, nesnenin maddi varoluşuyla değil biçimiyle ilgilenir. Görmek bu biçimlere odaklanmaktır. Fakat bunun öğretilebilir bir forma sokulması mümkün müdür? Sanat eserlerinin üretiminde alımlanmasında teknik beceri gereklidir ama bu beceri, mekanik sanatta veya zanaatta olduğu gibi birincil değildir (Kant, 2016, s. 121-122) ${ }^{7}$. Kaygı'nın da belirttiği gibi, "sanatın neliğini başvurulan malzemenin ustaca kullanılması olarak belirlemek sanat için tehlikeli bir yaklaşımdır" (Kaygı, 2006, s. 2).

Estetik sanatın öznesi, estetik idealar üreten ve ruhu yaratıcı bir biçimde şekillendiren dehadır. Kant, dehaya dört nitelik atfeder (Kant, 2016, s. 119-121). Birincisi, belirli hiçbir kuralın yönlendirmediği özgünlük olarak yetenektir. Dehanın eseri tekrar edilemez oluşuyla biriciktir. Ancak bu eser, diğer sanatçılar için örnek olabilir. Eserinin model olması, onun ikinci niteliğidir. Üçüncü niteliği, doğanın verdiği kurala göre üretmesidir. Bu kuralı kavramsallaştırmak ve çıkara göre açıklamak mümkün değildir. Onun son niteliği, bu kuralı bilimden değil sanattan türetmesidir. "Deha ve onun eylemi, en yüksek bireysellik ve en yüksek genellik, özgürlük ve zorunluluk, saf yaratıcılık ve saf yasallığın birbirlerine çözülmez bir şekilde geçtikleri noktada gerçekleşir" (Cassirer, 1996, s. 345). Bu sınırda "güzel bir şey üretmenin kuralı yoktur" (Schaper, 2005, s. 175).

O halde, şiir öğretmeninin görmenin önemini vurgulamasıyla, öğrenciler birden her bir nesneyi dolaysız görmezler. Öğretmen dersi anlatırken kullanacağı elmayı almak için yolunu uzatmıştır çünkü o, "diğerleri" gibi hazırlıksız değildir. Bunu ifade ettiği sırada Mija sınıfa girer, "diğerleri" gibi hazırlıksız gelmiştir. Şiirin öğretilebilir kabul edilmesine bir eleştiri gibi sınıfta yerini alır. Fakat öğretmen elma üzerinden şiiri öğretmeye devam eder. Elmayı milyonlarca kez görmemize rağmen, onun özünü hiçbir zaman görmemişizdir. Onunla hiç "iletişim kurmamış"8 ve "gün ışığını özümseyişini hayal etmemişizdir"9. Onun bu özünü yakalayabilmemiz için, "boş bir kağıt ve kalemle"10 beklememiz ve bu boş kağıda, "içinde büyük potansiyel barındıran, henüz yaratılmamış bir dünya" $\mathrm{yI}^{11}$ bırakmamız gerekir. Mija bu eğitimi, konuyla ilgisi olmayan şu sözlerle keser: "eskiden

7 Mekanik sanat, tasarlanan nesnenin bir kavrama uygun üretilmesidir. Ortaya çıkan ürün, kavramın belirlediği alanın dışına çıkamaz. Estetik sanatta, belirleyici bir kavram yoktur, eserin amacı nesneden duyulan hoşlanma duygusu yaratmasıdır. Mekanik sanatta ise amaç, ürünün yararıyla şekillenir. Teknik donanıma sahip zanaatçı, bu yarar ilkesini dikkate alır. O halde, sadece mekanik sanatlar öğretilebilir (Kant, 2016, s. 117-118).

8 00:20:50

$900: 21: 05$

$10 \quad 00: 21: 18$

$11 \quad 00: 21: 28$ 
ben de güzel kalem açardım"12. Hoca şaşırır ama Mija anlatmaya devam eder: "kalem açmakta iyi olduğumu söylerlerdi. Bütün kardeşlerimin kalemlerini ben açardım"13. Mija'nın hazırlıksızlığı yersizliğe dönüşür. Öğretmen buranın bir kurs olduğunu hatıllatır ve kursun sonunda herkes bir şiir yazmak "zorundadır"14. Mija bu zorunluluğu gerçekleştirmek için evinde görme "pratikleri" yapar. Sırasıyla bulaşıklara, buzdolabı üzerindeki çıkartmalara, elini alnına koyup uzaklara ve masanın üzerindeki elmaya bakar.

Sabah olur ve Mija evinin önündeki ağaca bakar. Yaşlı bir kadın neye bakıyorsun diye sorar. Mija ağaca diye cevap verir. Kadın bu sefer, "ağaca ne demeye bakıyorsun ki?"15 diye sorar. Mija cevap verir: "görmek için, hissedebilmek için, içinde sakladıklarını anlayabilmek ve bana fısıldadıklarını duyabilmek için"16. Kadın döner ve onun yanından uzaklaşır. Mija'nın görme pratiği torununun arkadaşlarından birinin babasının (Nae-sang Ahn) aramasıyla kesilir. Adamın görüşme talebine karşılık Mija şiir kursu olduğunu söyler. Adam ne kursu olduğunu anlamaz ve Mija üç kez "şiir" diye bağıır.

Öğretmen şiir yazmanın "güzelliği keşfetmek"17 olduğunu söyler. Ancak Mija'nın şiir yazma uğraşı, ağırlığını hissetmeye başladığımız kötülükle sürekli bozulur. Öte yandan, bu bozulmayı, yaşamın bütününde ele aldığımızda, sanatının kaynağı olarak da görebiliriz çünkü o, nesneleri görmeye çalışırken kendisini yaşamın akan canlılığında-nehrinde bulur. Estetik, yerini deneyimin öznesinde ve dehada beliren Kantçı "yaşama duygusu"na (Lebensgefühl) bırakır (Kant, 2016, s. 39). Bu duygu yaşamın rastlantısal bir momentinde değil, momentlerin toplamı olan yaşamın bütününde ortaya çıkar (Cassirer, 1996, s. 340). Doğadaki ve sanattaki güzel bu bütünlükten filizlenir. Altuğ'un da ifade ettiği gibi, "yaşama duygusu ile ilişkisi içerisinde bu yetinin (estetik yargı) estetik olarak yargıladığı, daha doğrusu değerlendirdiği şey, karşılıkı etkinlikleri içerisinde bilgi yetilerimizin gücünün artmasına ya da azalmasına yol açan bir tasarımın kapasitesidir" (Altuğ, 2007, s. 57). Mija bu duygudan estetik üretime doğru ilerler. Bu ilerleyişi kısaltabilmek için öğretmenine can alıcı soruyu sorar: "ilham ne zaman gelir?"18. Öğretmen cevap vermekte zorlanır; onu bulmak için "ayağına gitmemiz gerektiğini"19 söyler. Mija soruyu çevirerek yeniden sorar: "nereye gideceğim?"20. Öğretmen bilgisel olarak bunu belirleyemez. Anlama yetimizin iki formu olan zaman ve uzam şiir açısından bir belirlenime sahip değildir. Tasarımların uzam olarak dışımızdaki yerini ve zaman olarak içimizdeki gelişimde nereye denk geldiğini söylemek mümkün değildir. 
Deleuze, bilgi üretiminin ilk kutbu olan görünün saf biçimi olarak uzam ve zamanı "sunum", ikinci kutbu olan kavramı "temsil" olarak ifade eder (Deleuze, 2015 , s. 23). Sunum ve temsil arasındaki tekabüliyet bilgiyi üretir. Estetik deneyimde ise tekabüliyet ortadan kalkar. Sunum saf bir oluşa dâhil olurken, anlama yetisi bu oluşa anlam vermeye çalışır. Cassirer, estetik deneyimin bu özgül etkinliğini şu şekilde ifade eder:

Estetik bilinç, kendi içinde saf bir tamlık formuna ve bununla birlikte kendi saf ansal (o anki) kendine aitliğe (kendinin olmaya, Selbstgehörigkeit) sahiptir ki, bizzat bu saf ansal (o anki) kendine aitlik içinde, işte tam da ansal olmayan, tersine zaman dışı olan bir imlem (Bedeutung) yönü içerilmiş haldedir. Çünkü bizim nedensel bağ kurucu düşünmemiz içinde kavramsal yoldan objektifleştirdiğimiz ve emprik zaman sırası (ardışıkık, Succesion) ve zaman düzeni içerisine yerleştirdiğimiz "öncelik" ve "sonralık" denen şeyler burada artık ortadan kalkmış ve sanki zaman durmuş bir kesintiye uğramıştır (Cassirer, 1996, s. 331).

Estetik deneyimin zamanı askıya alması, onu amacı açısından da paradoksal kılar. Mija "neden şiir öğreniyorsun" sorusuna cevap veremez. Mija'nın estetik deneyimleri şematize edilmiş bilgisel bir modele göre belirlenemez. Kantçı estetiğin üçüncü uğrağı olan amaçsız amaca uygunluk bu deneyimin doğasını açıklar ${ }^{21}$. Kant'a göre, "kavram olmaksızın evrensel olarak iletilebilir olarak yargıladığımız hoşlanmayı, dolayısıyla beğeni yargısının belirlenim zeminini oluşturan şey, hiçbir erek olmaksızın bir nesnenin tasarımındaki ereksellikten, ve böylece bilincinde olduğumuz sürece bize bir nesnenin onunla verildiği tasarımdaki salt ereksellik biçiminden başka hiçbir şey olamaz" (Kant, 2016, s. 53). Nesnelerin insanda uyandırdığı duygulanım, ruhsal yetilerini harekete geçirdiği ölçüde amaçlıdır. Bu nesnenin bir amacı değil, öznede tahayyül edilen şeyin amaç olarak karşıığıdır. Amaç kavramının işlevsel olduğu alan, anlama yetisinin yasa koyucu olduğu duyulur dünyadaki deneyim alanıdır. Bu alanda, bir şeyin bilgisel olarak doğrulanması için diğer şeylerle her zaman zorunlu bir bağıntısı olması gerekir. Bu alandaki şeyler nedensellik bağıyla birbirine bağlanır. Estetik deneyimde bu bağ kopar ve özne kendisini bir oyun içerisinde bulur. Nesnenin öznedeki etkisi, onun özne açısından amaçlılığını oluşturur. Altuğ'un da ifade ettiği gibi, "yetilerin uyumu, beğeni yargısını, nesnenin amaçlılığına ilişkin bir duygu haline getirir" (Altuğ, 2007, s. 101).

Mija bu duygulardan hareketle bir şiir yazmaya çalışır. Mija, aslında, Kant'ın üç meşhur kritiğinin öncesinde kaleme aldığı "Güzellik ve Yücelik Duyguları Üzerine Gözlemler" eserindeki tavrına yakındır: "bir felsefecinin değil bir gözlemcinin

21 Kant, "Saf Akın Eleştirisi"nde ortaya koyduğu belirleyici yargının dört mantıksal işlevini derin düşünen yargı yetisine uygular. Bu dört işlev sırasıyla şu şekildedir: nitelik, nicelik, ereklerin ilişkisi - bağıntı ve kiplik. Nitelik, belli bir hoşlanma içeren ama ilgiden bağımsız olarak; nicelik, tümellik içeren ama belli bir kavramdan yoksunluk olarak; ereklerin ilişkisi, yani bağıntı amaçsız amaca uygunluk olarak; kiplik ise zorunluluk içeren ama kavramdan yoksun olduğu için kanıtlanamayan tümellik olarak kendisini gösterir (2016, s. 39-67). 
gözüyle bakmak" (Kant, 2017b, s. 49). Mija etrafındaki güzellikleri ve kötülükleri gözlemleme çabasındadır. Estetik deneyimden deha düzeyine yükselmesi, bu çabanın bir sanat eseri olarak cisimleşmesidir. Fakat bu üretim, doğrusal bir gelişim sürecine bağlı değildir. Mija ne için yazdığını bilmez ama bu amaca dair belirsiz de olsa anlam vermeye çalışır ve çocukluğundan kalan bir anısını anlatır. Öğretmeni bir gün şair olacağını söylemiştir. Bu anıya karşılık başka bir soru gelir: "siz de şair olmak istediniz, öyle mi?"22. Mija'nın amacı şair olmak değil, sadece bir şiir yazmaktır. Fakat şiir nedenin bilgisinden yoksunluktur ve şair bu uğraşın ne için olduğunu bilmez. Şiir, bir şeyin aracı değildir, amacını kendinde taşır.

\section{Kötülüğün Retoriği ve Öznedeki Sanat Duygusu}

Bir sonraki sahnede Mija'yı çocukların babalarıyla görürüz. Mekânda intihara neden olan suçun konuşulacağına dair bir atmosfer yok gibidir. Saf bir kötülükle karşı karşıyayızdır. Her bir baba suçun neden olabileceğine dair anlamlar bulmaya çalışır. Her bir anlam bulma uğraşı, suçu kabul edilebilir bir nedenin sonucu olarak gösterir. Olayın mantıksal sunumuna ulaşılığında, kutlamanın ifadesi olan içkiler tokuşturulur. Olayın ayrıntılarını daha fazla dinleyemeyen Mija odadan ayrııı ve odanın camının önündeki çiçeklerin yanına gider. Çerçeve değişmeden kalır, ön planda babalar konuşmaya devam ederken arka planda Mija çiçeklerle oynar. Olayın çözümüne dair ifade edilenlere görüntünün iki karşıt içerikli katmanı eşlik eder. Olayın çözülebilmesinin tek yolu kızın ailesine para vermektir ama bunun için ailenin ikna edilmesi gerekir. Bakışlar çiçekleri seven Mija'ya yönelir. Hiçbiri ne yaptığına anlam veremez. Tecavüze kendi çocukları açısından anlam bulmaya çalışan insanlar, yaşı bir kadının çiçekleri sevmesini anlamsız bulur. Mija çiçeklerin başında yazacağı şiir için not alır. Film boyunca aldığı notlar sayfa olarak gösterilirken sadece bu not gösterilmez. Belki de bunun nedeni, notu almasına vesile olan çiçeğin "çiçek dilindeki anlamında" ${ }^{23}$ saklıdır: "kalkan". Mija bunun bizi koruyan kalkan olduğunu düşünür. Kendini odanın içindeki kötülükten, çiçekle, yani doğadaki güzelle korumaya çalışır. Ancak bu korunma edimi film boyunca çözülmeye başlar. Mja kendisini kapana kısılmış olarak bulacaktır. Bunun işareti aldığı notta saklıdır: "kan".

Mija suça dair bir şeyler bulmak için torununun odasını arar. O sırada yanıışıkla bilgisayarda çalan müziğin sesini açar. Kapamaya çalıştıkça müziğin sesi daha çok yükselir. Odanın sahibinin suçu olanca gücüyle üstüne çöküyor gibidir. Müziği kapatmaya çalışırken klavyeyi bir piyano gibi kullanır ve şiddetle klavyenin tuşlarına basar. Bastıkça sesler yükselir, tutkulu bir müzisyen gibidir. Bilgisayarın fişini çektiği sırada telefon çalar. Bulmaya çalıştığı şeylerle dolanmış olduğu odadan hızla uzaklaşır. Ancak mekânsal olarak uzaklaşabilir çünkü arayan kişi çocukların birinin babasıdır. Okul müdürü onlarla görüşmek ister. Buluşurlar ve sessizlik yemini ederler. 
Mija, torununun televizyon izledikten sonra ardında bıraktığı şeyleri toplamasını ister. Bu talep, biraz sonra yaşanacak duygusal patlamanın ve torunuyla ilgili alacağı kararın işareti gibidir. Gece olduğunda onun odasına girer ve bir şey konuşmak istediğini söyler. Talebin ve duygunun ölçüsü artar ve sonunda onun üstündeki yorganı kaldırarak "neden yaptın bunu?" 24 diye haykııır. Haykırışlar eşliğinde onu silkelerken üzerindeki kanlı toprağı dökmeye çalışıyor gibidir. Mücadele sona erer ve hüzünlü bir kabullenişle odadan ayrılır. Sabah olduğunda öfke sevgiye dönüşür. "Dünyada en çok sevdiği şey Wook'un (torununun) karnını doyurması" 25 dır.

Şiir kursunda, birkaç kişi sırasıyla kalkarak yaşamdaki güzel anılarını anlatır. İk anlatıcı büyükannesine müzik öğrettiği anı aktarır. İkinci anlatıcı doğum yapmasını ve çocuk sahibi olmasını anlatır. Doğum yaparken "güneş gibi bir şeyin kaydığını" 26 hissetmiştir. Üçüncü anlatıcı güzel anım yok diye başlar. İçlerinden güzel olabilecek olanını seçer. Biraz daha büyük eve çıktığında "yere yatıp kollarını ve bacaklarını açmış" ve "sanki bütün dünya onun olmuştur"27.

Mija torununun okuluna gider, bir banka oturur ve bahçede top oynayan çocukları izler. Bir kuş sesi duyar, başını kaldıır ve sesin kaynağını görmeye çalışır. Filmin başındaki kuş sesi ve oyun, farklı öznelerle sergilenmeye devam eder. Cesedin görülmesinden önceki ses, o ölümün nedeni olan tecavüzün yapıldığı mekânda yankılanır. Mija çantasından defterini çıkarır ve şu notu alır: "kuşların cıvıldayışları, hangi şarkıyı söylüyorlar?" 28. Yerinden kalkar ve tecavüzün yapıldığı laboratuvara gider.

Mija'yı akşam şiir dinletisinde görürüz. İçeri girdiğinde, birisi şiir okumaktadır; arkalarda bir masaya oturur ve şiirin en can alııı dizesi yükselir: "şiir yazmak, hiçliğin ormanını yaratmaktır" 29 . Sunucu diğer şairi takdim eder. İkinci şair, şiirinde ağustos böceğinin tutku dolu yaşamını anlatır. Okunan şiirlerin bazı dizeleri Mija'nın yaşamına dokunur. Mija kötülüklere rağmen, süslenerek ve etrafına gülücükler saçarak yaşam dolu tutkusunu dışa vuran bir insandır. Ancak bu tutku, onu "hiçliğin ormanına" varmaktan kurtarmaz. Filmin sonunda, hiçliğin diyarı olan ölüme doğru ilerleyecektir. Üçüncü kişi (Jong-goo Kim) sahneye çıkar ve bir şiir okur. Şiirdeki cinsel unsurları esprilerle abartarak kaba bir üslupla aktarmaya çalışır. Sanki şiir okumuyor da dilin inceliklerini kullanarak şiiri ek açıklamalarla boğuyor gibidir. Kant'ın konuşma sanatlarına dâhil ettiği ve şiirin karşısında konumlandırdığı "retorik" içerisinde kalır. Kant'a göre, "konuşmacı bir iş için söz verir ve onu yalnızca dinleyicilerini eğlendirmek için sanki idealar ile bir oyunmuş gibi yerine getirir" (Kant, 2016, s. 130). Bu bağlamda, üçüncü kişi, "anlama yetisinin bir işini hayal gücünün özgür bir oyunu olarak sunmaya" (Kant, 2016, s. 130) çalışır. Son

24 00:51:25

$2500: 52: 46$

26 00:55:03

$2700: 56: 00$

$2800: 57: 12$

29 00:59:55 
şiirin ardından Mija, ilk şiir okuyan kadına "nasıl şiir yazdığını"30 sorar. Kadın şiirin öznel doğasına vurgu yaparak duygulara gönderme yapar. Bu sahnedeki özne ve "içerisi" vurgusu Kant felsefesi açısından önemlidir çünkü tüm yetilerin işleyişinde Kant felsefesi açısından araştııılan konu bu işleyiş içerisindeki "öznel katkı"dır. Onun felsefesini bir "özne felsefesi" olarak görmek yanlış olmayacaktır (Altuğ, 1995, s. 11). Bu yetiler içerisinde en öznel olanı ise, estetik deneyimi oluşturan beğeni yargısı ve hoşlanma veya hoşlanmama duygusudur. Oyundan türeyen "yaşama duygusu" da öznede ortaya çıkan bir duygudur. Öznelliğin en saf biçimi olan estetik deneyim, nesnel bir yönelime bağlı olan bilgi düzleminden ayrıdır (Schaper, 2005, s. 160). Fakat Adorno, söz konusu öznelliğin "öznedeki nesnellik" olduğunu savunur. Bu bağlamda, Kant felsefesini de bu nesnelliği "nesnel bir gerçeklik olarak temellendirmeye yönelik bir proje" olarak kabul eder (Adorno, 2005, s. 56). Estetik deneyim özelinde düşündüğümüzde, Kant'ın bu deneyimde öne çıkardığı duygulanım hali, özneyi merkeze yerleştirdiğinin göstergesidir.

Mija'nın şiir yazmasına yönelik kendine, yani özneye ve duygularına dön çağrısına kulak vermesi zor ve sancılı olacaktır. Kötülükler sürekli önünü keser. Bakımını yaptığı adamın evine gider. Adam Mija'ya cinsel hazzı artırııı bir ilaç uzatır ve içmek istediğini dile getirir. Mija adamı yıkarken ilacın ne olduğunu anladığında sinirlenerek onu o halde bırakır ve evi terk eder.

\section{Kavram ve Unutkanlık}

Mija doktorunun tavsiyesine uyarak daha büyük bir hastaneye gider. Soğuk renklerin hâkim olduğu doktor odasında, camın önündeki kamelyaları fark eder. Hastalığı hakkında konuşmadan önce, doktora çiçekleri anlatır. Kırmızı renkli kamelyalar kışın ve acının çiçeğidir. Doktor şaşııı, hastane odasındaki bir çiçeğin böylesi bir anlamı olduğunu düşünmemiştir. Bu anlam şüphesiz çiçeğe ait değildir, Mija'nın şairane ruhunun bir dışa vurumudur. Fakat doktorun bu anlamdan haberinin olmaması gibi, bu ifadeyi de çiçeğin özü olarak kabul edemeyiz. Acıyı simgeleyen çiçeğin aynı zamanda aşkı veya umudu simgelemesi de muhtemeldir, tıpkı "beyazın bekaret ve sarının intişamı" ${ }^{31}$ simgelemesi gibi. Bütün bu anlam atfetmeler, Mija'nın da dediği gibi şiiri öğrenmenin adımlarından biridir. Nesnelere atfedilen anlamları değişmez gibi kabul etmek şiiri öğretilebilir bir forma indirgemektir. Doktor onun şiir yazmasının önündeki muhtemel engeli veya yazmasına "katkı"da bulunacak nedeni dile getirir. Mija Alzheimer hastasıdır. Mija'nın şiir yazmasıyla ilgili olarak hastalığına dair bu ikircikli bakışın nedeni, Kant'ın estetik deneyimde kavramlara biçtiği rolle ilgilidir. Bu bağlamı aydınlatmak adına, Kant'ın beğeni ilkesi için öne sürdüğü antinomiye göz atmak gerekir:

1. Sav: Beğeni yargısı kavramlar ile temellendirilemez; yoksa üzerinde tartışmaya (tanıtlamalar yoluyla karara) izin verirdi.

2. Karşısav: Beğeni yargısı kavramlar ile temellendirilebilir; yoksa türlülüğüne karşın, üzerinde çekişmek (başkalarının bu yargıya 
zorunlu onayları için istemde bulunmak) bile söz konusu olamazdı (Kant, 2016, s. 143; 2007, s. 166).

Kant, bu çelişkiyi ortadan kaldırmak için, kavramın her iki savdaki anlam farkılığına dikkat çeker. Birinci savda kavram, belirli bir anlamı ifade eder (anlama yetisinin kavramları gibi); ikinci savda belirlenimsiz bir anlamı ifade eder Tümellik talebinde bulunmak için kavram zorunludur. Fakat bu kavram, anlama yetisinin kavramları gibi belirli değildir. Antinomide yer alan bu paradoksu, öznellik ve nesnellik açısından değerlendirebiliriz (Altuğ, 2007, s. 168). Her beğeni yargısı, yargı veren öznede hissedilen bir duygu olması itibariyle özneldir. Ancak aynı zamanda, evrensellik ve zorunluluk iddiası taşıdığı için de nesneldir. Beğeni yargısının bu iki karşıt ilkeyi aynı anda barındırması, film bağlamında Mija'nın şiir yazmasını da paradoksal hâle dönüştürür. Mija'nın önce isimleri sonra eylemleri unutmasına neden olacak hastalığı, şiir yazma açısından kavramın belirli olan anlamında olumlu, kavramın belirsiz olan anlamında ise olumsuz bir etki olarak okunabilir. Mija yazmaya çalıştığı şiire yaklaştıkça kavramlardan uzaklaşmaktadır. Unutmanın şiddeti arttıkça şiire ulaşacağı vakit daralmaktadır.

Öte yandan, Mija'nın şiire ulaşmasıyla kavramları unutması arasındaki koşutluk, Kant'ın güzel ve iyi arasında kurduğu ilişkiyle de bağıntııdır. Kant, güzeli iyinin "sembolü" olarak görür (Kant, 2016, s. 154)32. Dehanın ortaya koyduğu eserler estetik idelerden oluşur. Kant'ın tine doğrudan yer verdiği bağlam da burasıdır ${ }^{33}$. Ona göre tin, "estetik ideaları sergileme yetisinden başka bir şey değildir" (Kant, 2016, s. 124). Altuğ'un da ifade ettiği gibi bu ideler belirlenimsiz kavramlardır: "hayalgücünün bu tasarımları, bir kavrama, çok daha fazla dilegetirilemez düşünce katmakla, kavramı belirlenimsizleştirirler" (Altuğ, 2007, s. 206-207). Fakat Kant akıl idelerini, estetik idelerden oluşan estetik deneyimin zeminine yerleştirir (2016, s. 154). Schaper, akıl idelerinin estetik idelerin temeline yerleştirilmesinin, estetiğin özerkliğini olumsuz etkilediğini savunur. Çünkü ona göre, güzeli ahlakın sembolü olarak görmek, "bir beğeni kuramından metafizik anlamında uzaklaşmaktır" (Schaper, 2005, s. 165). Bunu bir uzaklaşma olarak değil, bir tür buluşma olarak da görmek mümkündür. Kant açısından estetik ideler kavramsız görülerken akıl ideleri görüsüz kavramlardır ve bu ideler, bir sanat eserinde bir araya gelir (Kant, 2016, s. 145-146). Žižek de meseleye bu açıdan yaklaşır. Onun açısından bir beğeni yargısı, "tikel bir nesneye evrensel bir kategori yüklemek ya da bu nesneyi zaten verili olan evrensel bir belirlenmişliğin altındaymış gibi düşünmek yerine, 'benim' bu nesnenin evrensel-zorunlu-bağlayıcı boyutunu keşfettiğim ve böylece bu tikel-olumsal nesneyi (edimi) bir ahlaki Şey derecesine yükselttiğim

32 Kant, bir kavramın sunumunu (hypotyposis) ikiye ayırır: şematik olarak sunum ve simgesel olarak sunum. Anlama yetisinin kavramlarını duyusallaştıran şemalardır. Bu sunumda dolayım yoktur, bilgisel nitelik taşır. Simgesel sunumda ise aklın kavramları söz konusudur. Bu kavramların duyulur dünyada kendilerine denk gelecek karşılıkları yoktur. Dolayısıyla, sunum zorunlu olarak sembolik olmalıdır. Sembolik biçim ise ancak dolaylı ve anolojik olacaktır. (2016, s. 153).

33 Heimsoeth'e göre, "Kant'ta Geist (tin) kavramı, ilk kez ve sadece estetikte ortaya çıkar. Bu kavram sonraları Hegel'de, akıl kavramı yanında, felsefenin geniş bir alanının ilgi merkezi olmuştur" (2016, s. 159). 
yargı"dır (Žižek, 2005, s. 188). Güzel ve iyi arasındaki bu ilişkinin film evreninde bir karşılığı olacaktır. Filmin sonunda göreceğimiz şiir, kötülüklere karşı yazıımış dizelerden oluşur. Bu bağlamda, etik düzlemle doğrudan bir ilişki içindedir.

Mija, ölen kızın annesine verilecek tazminatın kendisine düşen payını bulmak umuduyla onunla iletişim kuran babanın iş yerine gider. Parayı unutur ve oradaki bir karaoke odasında şarkı söyler. Şarkının son sözü, alınan son notla ve hastalığıyla doğrudan ilişkilidir. Adamın odaya girdiğinden habersiz şarkının şu son sözünü haykırır: "unutkanlık şarabından bir kadeh daha içmek istiyorum" ${ }^{34}$. Bu şarabın son yudumu ise şiir olacaktır.

\section{Doğanın Dili Olarak Sanat}

Mija'yı kızın intihar ettiği köprüde görürüz. Köprünün demir parmaklarına yaklaştığı sırada şapkası uçar. Önce paniğe kapılır, ancak sonra, teninde ve saçlarında hissettiği rüzgâr nedeniyle tebessüm eder. Şapka havada dolaşır ve kızın kendisini attığı köprünün altındaki nehre düşer. Nehir, ölen kızın cansız bedenini sürüklediği gibi şapkayı da sürükler. Sanki akan nehir Mija olmuş da şapka bu doğa güzelliği üstündeki beyaz bir çiçek gibi durur. Önce rüzgârla, sonra nehirle duyumsanan bu bütünlük, biraz sonra yağmurla tamamlanacaktır. Mija nehrin kenarına iner ve not almak için çantadan defterini çıkarır. Not alacağı şeyi düşünür, kafasını gökyüzüne kaldırır ve perde boş bir sayfanın görüntüsüyle kaplanır. Mija'nın kelimeleri dökülür: yağmur damlaları. Nehir yağmur damlalarına kavuşur, yağmur damlaları kaynağına geri döner, çembersel hareket tamamlanır. Mija yağmur damlalarıyla not alır ve not aldığı kelimeler, onu sırılsıklam bırakmıştır. Yağmur altında hiç kımıldamadan uzun bir süre bekler. Derin bir düşünüm halindedir ve bu düşünceli halin bir karar olarak yansıması bir sonraki sahnede görülür.

Mija'nın bu sahnede doğayla bütünleşmesi onun şiir yazma uğraşıyla beraber düşünüldügünde, Kant estetiğiyle ilişkilendirilebilecek başka bir bağlam ortaya çıkarır. Mija'yı şiir yazması açısından bir deha olarak kabul edebiliriz. Kant açısından deha, doğuştan (innate) gelen bir yetenektir ve doğa sanata kuralını onun aracılığıyla verir (Kant, 2016, s. 119-120). Deha yaratıcı sanatçıya ait olmakla birlikte, onu aşan aşkınsal bir ilkedir. Bu yetenek doğuştan geldiği için aslında doğaya aittir. Dehanın sanat eserleri de, Cassirer'in de ifade ettiği gibi, "yeni bir bütünlük, yeni bir gerçeklik tablosu, yeni bir tinsel kosmos" bulduğumuz dünyaların kapısını açan oluşumlardır (Cassirer, 1996, s. 327). Fakat bu oluşum doğanın sınırlarını aşmaz çünkü deha, doğanın kendisine sunduğu imkân koşulunca yaratabilir. Altuğ'un da vurguladığı üzere, "sanat doğanın konuşamayan (sessiz) dilini konuşur kılmaya çalışır" (Altuğ, 2007, s. 184). Bu bağlamda, sanatın doğayı tamamladığını veya sanatın doğayla birlik içerisinde olduğunu söylemek yanlış olmayacaktır. Doğanın sanat ürünleri içerisindeki bu merkezi konumu (hem malzeme olarak içeriği hem de malzemenin biçimlenmesindeki kabiliyeti sağlaması) dehayı ve onun eserlerine nüfuz eden özneleri doğanın bir parçası kılar (Schaper, 
2005, s. 176). Kant'ın da belirttiği gibi, "doğa nasıl ki sanat görünüşü edindiği zaman, güzel ise, sanat da, biz onun sanatsal var oluşunun bilincinde olmamıza rağmen, doğanın görünüşüne sahip olduğunda, güzel olarak ifade edilendir" (Kant, 2016, s. 119; 2007, s. 135). Bu sahnede, sanat ve doğa arasındaki bu birliği görürüz. Mija'nın rüzgârla ve nehirle bütünleşmesi ve şiir dizelerinin bulunduğu sayfalara yağmur damlalarının karışması, sanat ve doğa arasında Kantçı anlamda böylesi bir birlik sunar.

\section{Unuttukça Güzelleşen Doğa}

Intihar eden kızın annesinin ikna edilmesi için belirlenen en uygun aday Mija'dır. O, torununa bakmaya çalışan fakir ve yaşı bir kadındır. Bu sıfatlarının yanına biraz gözyaşı eklediğimizde, sonuç kesinlikle "başarılı" olacaktır. Mija'dan istedikleri şey, tam olarak Kant'ın söylev sanatı için söylediği şeydir. Kant bir dipnotta, söz sanatları olan şiir ve retoriğin karşısına söylev sanatını koyar. Ona göre, "söylev sanatı (ars oratoria), birinin insanların zayıflıklarını kendi amaçları için kullanması sanatı (bu amaçlar niyette iyi olabildikleri gibi giderek edimsel olarak da iyi olabilirler, ama bunun bir önemi yoktur) hiçbir saygı hak etmez" (Kant, 2016, s. 135). Mija'dan istenilen şey de, kızın annesine böylesi bir sanat sergilemesidir. Kızın ailesinin paraya intiyacı vardır çünkü babaları da yoktur ve diğer çocuğunun geleceği için annenin bu parayı alması gerekir. Öte yandan bunu sağlamak için sadece bu zayıflıktan faydalanılmaz. Kendisiyle benzer durumda olan bir kadınının, yani Mija'nın kullanılmasıyla annenin duygusallığından da faydalanılır.

Mija kızın köyüne gider ama kıyafetleri çok süslüdür, köye "uygun" değildir. Tedirgin olan Mija geri dönmek ister. Ancak asıl önemli olanın kıyafetler değil, "kelimeler" olduğu telkin edilir. Fakat Mija, kavramları çoktan unutmaya başlamıştır. Kızın annesini bulmak için tarlaya doğru giderken cennetin bir bahçesinden geçer gibi huzurlu ve mutlu bir hali vardır. Onu doğayla bütünleşmiş bir biçimde tekrar görürüz. Gidilen yolun çevresine, bir notunda da yer alan "kuş seslerinin cıvıldayışları" hâkimdir; açık bir havada, etrafını ağaçların ve çiçeklerin kuşattığı bu yol üzerinde ilerler. Ağaçlar da tıpkı kendisi gibi çok "süslü"dür ve yolu, o ağaçlardan düşen kayısılar kaplamıştır. Mija, kayısılardan birini yedikten sonra not almak için defterini çıkarır. Yaşamın döngüselliğine veya bütünlüğüne gönderme yapan şu notu yazar: "kayısı, kendisini yere atıyor. Bir sonraki hayatına başlamak için, ayaklar altında çiğnenip eziliyor" 35 . Savaş'ın da ifade ettiği gibi Mija, "yalnızca güzel görünenleri değil, hemen yanı başımızdaki, bazen ayaklar altında ezilen, çürüyen şeylerdeki güzelliği de görmeye, sevmeye ve anlamaya çalışır" (Savaş, 2020, s. 22).

Elinde ısırdığı kayısıyla ilerlerken kadını görür ve yanına yaklaşarak havanın ve manzaranın güzelliğinden bahseder. Sanki o kadının kızına tecavüz eden ve kızın intihar etmesine neden olan torunu değilmiş gibi, oradan geçerken gör-

$35 \quad 01: 38: 30$ 
düğü herhangi bir insanla sohbet edercesine konuşur. Onun kim olduğundan habersiz olan kadın da, bu sohbeti büyük bir keyifle sürdürür. Elindeki kayısıyı gösterirken çok güzel olduğunu dile getirir; kadın ise onun aldığı notu hatırlatırcasına, en güzel ve lezzetli olanların ağaçtan düşenler olduğunu dile getirir. Mija yere düşen kayısıları "özlem dolu" bulur ve olabilecek en güzel formuna, yani ereğine ulaştığı zaman bir sonraki yaşamına kavuşmak için özlemle kendilerini toprağa fırlattıklarını düşünür. Kayısılara baktığında ilk "gördüğü" şey budur. Bu güzel manzaranın içinde yürürken kendisini "kutsanmış" gibi hisseder. Çiçeklerin seyrinden sonsuz bir mutluluk duyar. Kadın bu mutluluğu, çiçeğe değil Mija'nın güzelliğine bağlar. Güzelliklerin süslediği bu "ikna etme" konuşması biter ve Mija kibarca kadının yanından uzaklaşır. Uzaklaşırken arka planda kadını görmeye devam ederiz. Mija'nın yüzünde, mutluluktan acıya doğru ilerleyen dönüşüm sergilenir. Mija artık uyanmıştır, kadınla konuşma amacını unutmuştur. Tedirginlikle arkasındaki kadına bakar ve hızla oradan uzaklaşır. Unutma edimi artık kavramlardan eylemlere uzanmıştır.

\section{İyinin Sembolü Olarak Şiir ve Etik Bir Eylem Olarak Yüce}

Mija şiir dinletisine tekrar katııır. Bir şiirde Mija'nın ilerlediği sona dair dizeler işitiriz: "sevdiğin gibi..sebat ettiğin gibi öl"36, öldükten sonra, "gökyüzünde asılı bir taş üstüne, tapınağımı inşa ederim" ${ }^{37}$. İkinci şiir okuyan kişi, tekrar retorik sanatını sergiler. Mija şiiri aşağıladığı için ondan hoşlanmaz. Ona göre, "şiir sevgisi güzelliğin peşinden koşmaktır" ${ }^{38}$. Fakat o adama dair hiç beklemediğimiz bir bilgi ediniriz. Önceki yerinde rüşvet toplayanları inbar eden bir polistir. Bu bilgiyi sunan kadın (bir önceki dinletide şiirin öznel doğasına vurgu yapan karakter), Mija'nın onun hakkındaki düşüncelerini polise aktarır. Mija'nın utandığını gören polis, pişmanlığını göstermek için ona içki sunar. Güzel bir şiir yazmaya çalışan Mija, şiiri "aşağılayan" kişinin içkisinden alırken odaya şiir öğretmeni ve bir şair gelir. Öğretmene göre şiir ölmektedir ve böylesi bir topluluğun olması umut vericidir. Ancak genç şair hemen müdahale eder: "şiir ölmeye mahkumdur!"39. Şiirin "güzelin peşinden koştuğuna" inanan Mija, şiiri "ölüme" götüren kötülükleri umursamayarak hep peşinde olduğu soruyu öğretmenine tekrar yöneltir: "nasıl şiir yazabilirim?"40. Öğretmen tekrar kaçamak bir cevap verir, "şiirin içimizde olduğunu ve kanatlanıp uçması gerektiğini" ${ }^{41}$ dile getirir. Genç şair gülerek tepki gösterir, öğretmenin böyle bir şey söylemesini gülünç bulur. Mija'nın dışarıda ağladığını gören polis, ne olduğunu öğrenmek ister ama Mija karşılık vermez. Daha doğrusu, söylediği şeylerin sonucunu biz filmin sonunda görürüz.

Mija eve geldiğinde intihar eden kızın kilisedeki cenazesinden aldığı fotoğrafını masaya koyar. Sabah olduğunda torunu gelir ve masanın yanındaki 
sandalyeye oturur. Kızın fotoğrafını görünce torununun vereceği tepkiyi merak eden Mija, kahvaltı hazırlamayı bırakarak onu seyreder. Torunu fotoğrafı fark ettiği zaman ona şaşkınlıkla bakar ancak beklenilen itiraf gelmez. O sadece açtır ve bir şeyler yemek ister. Fotoğrafın yanındaki kumandayı alır ve televizyonu açar. Kahvaltıdan sonra Mija, dışarıda çocuklarla beraber oyun oynayan torununu izler.

Kızın annesi artık ikna edilmiştir. Anneyi gören Mija, onunla ilk karşılaşmasını hatırlayarak utanır; anne ise, şaşkınlıkla onu seyreder. Mija'nın anneyle olan diyaloğunu hatırlarsak, annenin Mija'ya tepki göstermemesi dikkat çekicidir. Belki o da, parayı kabul etmesinin utancını yaşamaktadır. İkisi de ant içmiş gibi tanıştıklarını söylemez. Mija bu utanca daha fazla dayanamaz ve mekândan ayrılır.

Para bulma konusunda köşeye sıkışan Mija, soluğu bakımını yaptığı adamın evinde alır. Mija adamla yalnız konuşmak ister adamdan "borcunu" almaya gelmiştir. Bu talebini iletmek için kalem ve defter kullanır. Şiir yazabilmek için alınan notların biçimsel sunumu, şantajla para istemenin biçimsel sunumuna dönüşür. Sayfalara düşen güzel ifadelerin yanında, artık kötülüğün bulaştığı ifadeler de yer alır. Parayı alır ve babaya götürür. Bundan sonra merak ettiği tek bir şey vardır: "her şey bitmiş midir?"42.

Herkes gibi yaşayamayacak olan Mija, sanki torununu kutlu bir olaya hazırlıyor gibidir. Torunu aynı günün sabahı masada tecavüz ettiği kızın fotoğrafını görmesinden sonra gelen bu ilgiye şaşırır. Beklenilen ama bilgisinden yoksun olduğumuz ana dair tüm hazırlıklar yapılır ve şimdi oyun vaktidir. Oyun film dünyasındaki son işlevini yerine getirir. Oyun devam ederken polis ve arkadaşı gelir. Çocuğun attığı top, Mija'nın görme "pratiklerinin" nesnesi olan ağaçlardan birine takılır. Mija ağaca döner ve topu almaya çalışır. Topu almaya çalışırken polisin arkadaşı çocuğu yanına çağııır. Top yere düşer ve Mija topu alıp doğrulduğunda karşısında torunu yerine polisi bulur. Torunu polisin arkadaşıyla yanlarından uzaklaşırken Mija'yla göz göze gelir. Her ikisi de bir şey söylemez. Polis Mija'yı tekrar oyuna çağııı. Mija torununa arkasını döner ve oynamaya devam eder. Kötülügün cisimleşmiş hali olan bir suçun karakterlerin yaşamına ilk teması oyunla olmuştur ve bu suçun faillerinden biri, Mija tarafından oyunla adalete sunulmuştur.

Bu eylemin Kant estetiğindeki karşılığı ise yüce kavramıdır. Kant, güzel ve iyi arasında kurduğu ilişki gibi yüceyi de iyiyle ilişkilendirir. Bu ilişkinin temel unsurunu ise "ahlaksal idealar" arasında bulur ${ }^{43}$. Yücenin bölümlenmesinde iki tarafı paylaşan matematik ve dinamik yüce, iyi olanla bağlantıyı

42 02:01:45

43 Kant, yüceyi ikiye ayırır: matematiksel ve dinamik yüce. Matematiksel yüce doğadaki mutlak büyüklük ile ilgiliyken, dinamik yüce doğadaki güç ile ilgilidir. Mutlak büyüklük olarak matematiksel yüce tasarlanan amaçılı̆̆ı bilgi yetisiyle ilişkiye sokarken, mutlak güç olarak dinamik yüce, tasarlanan amaçılıı̆ı arzulama yetisiyle ilişkiye sokar. (2016, s. 74-88). 
oluşturur. Nasıl ki matematiksel yücede hayal gücünün yetersizliği aklın bütünlük, sonsuzluk ve sınırsızlık gibi idelerini harekete geçirerek bizim ahlaki varlığımızı öne çıkarıyorsa, dinamik yücede de fark edilen direnme gücü amaç olarak insanlık idesini öne çıkarır. Özne, aklın bu duyuüstü idelerinin ortaya çıkışında bir ritim bulmaya çalışırken kendisini bir kaosun içinde bulur (Deleuze, 2015, s. 108). Kuehn'in de belirttiği gibi, "yüce, tasarımın sınırsızlığını içerir" (Kuehn, 2011, s. 351). Schaper ise, estetik deneyimde şekillenen yücenin, tasarımın sınırsızlığına bağlı olarak aklın duyuüstü idelerine bağlanmasını, bir tür üstünlük açısından yorumlar (Schaper, 2005, s. 169). Aklın bu ideleri, imgelem yetisini bastırarak ona üstün gelir. Schaper'in güzelin iyinin sembolü olmasına yönelik özerklik eleştirisi burada da iş başındadır. Fakat Deleuze'ün de belirttiği gibi, imgelem özerkliğini kaybediyor gibi görünse de, "kendi sınırını nesne edinerek aşkın bir ilerleyişe yükselir" (Deleuze, 2009, s. 100). O halde, bu karşılıklı işleyişi bir üstünlük formuna göre değil yetilerin işleyişindeki bir uyum olarak görmek, Kant felsefesi açısından daha uygun olacaktır. Film evreninde Mija, bu uyumun vücut bulmuş halidir. Sadece şiir yazma uğraşıyla değil, etik bir eylemde bulunmasıyla da, film evreninde ahlaki bir düzlem açar. Kant, yücenin harekete geçirdiğini, güzelin ise büyülediğini savunur (Kant, 2017b, s. 51-53). Mija etik bir eylemde bulunarak yücenin alanına geçer. Onun bu soylu eylemi bizde saygı uyandırır. Öztürk'ün Haneke'nin "Amour" filmiyle tartışmaya açtığı Kantçı görev etiği bu filmde de karşımızdadır (Öztürk, 2018, s. 54-55). Mija, evrensel sahaya geçmek için özel ilişkilerini aşarak görev etiğine uygun bir eylemde bulunur.

Kant, yücenin sadece doğada ve sanatta değil, insan edimlerinde de olabileceğini savunur (Kant, 2016, s. 85-96). Film bağlamında, söz konusu edim, kötülüğe dayalı ilişkilerde ortaya çıkmıştır. Kant, yüce ve kötülük arasında da bağlantı kurar ve bu bağlantı yücenin güzelden bir ayrımını da içerir: "yazgının başka insanlara getirdiği kötülüklere dayalı olan hüzünden (ki nedeni duygudaşlıktır) ayrı olarak, insanların birbirlerine yaptıkları için duyulan hüzün (ki ilkelerde bağdaşmama üzerine dayanır) yücedir; çünkü idealar üzerine dayanır; oysa birincisi yalnızca güzel sayılabilir" (Kant, 2016, s. 96). Bu ayrımı film evrenine taşırsak, Mija filmin başında hastane önündeki kadının acısını gördüğü zaman, Kant'ın birinci tanımındaki duygudaşlık sınıflandırmasında kalmıştır. Fakat duygudaşlık temelinde deneyimlediği acı ve kötülük kendisi de dâhil etrafındaki tüm insanlara bulaştığı zaman, tüm insanlardan ayrılarak etik duruşunu korumaya çaıışmıştır. Torununu kendi elleriyle teslim etmiş ve bu duruşuyla da diğerlerinden ayrılarak insanlığa son eylemini sunmuştur. Öte yandan, iyinin kavşağında yer alan bir diğer birleştirici öğe, yani güzel, karakterin dünyada var olma biçimiyle ve doğadaki nesnelere dair beğeni yargılarıyla ortaya çıkmış olsa da, eser olarak henüz ortada yoktur ve şimdi, iyinin sembolü olarak güzelin estetik sanat formunda kendisini gösterme zamanıdır.

Kursun artık son günüdür. Olmadığı sınıfta sadece Mija, verilen "ödevi" yerine getirerek şiir yazmıştır. Öğretmen bu şiirin adını duyurur: "Agnes'in Şar- 
kısı". Agnes, intihar eden kızın adıdır. Şiirin adıyla beraber Mija'nın evine geçilir. Mija evde yoktur ve kızı onu bulmaya çalışır. Mija'nın "Agnes"e sunduğu "Şarkı", Mija'nın sesiyle dış ses olarak yankılanır ${ }^{44}$.

Hava nasıl oralarda?

Issiz mı yine?

Mija'nın "görmeye" çalışığı ağaç, tepeden tırnağa gösterilir. Ağacın altında, Mija ağacı "görmeye" çalışırken "ne demeye bakıyorsun ki?" diye soran kadın ağacı izlemektedir:

Gün batımı hâlâ ateş kırmızısı mı?

Orman yolundaki kuşlar, şarkı söylüyorlar mı?

Kızı evden çıkar ve kapının önündeki kadınlara Mija'yı sorar. Görüntünün ön planında çocuklar oyun oynamaktadır:

Yollamaya cesaret edemediğim mektubu kabul eder misin?

Söylemeye cesaret edemediğim itiraflarımı dinler misin?

Zaman geçecek mi?

Güller solacak mı?

Mija'nın kullandığı duraktan bir otobüs kalkar ve uzaklaşır. Otobüs, kız öğrencilerin yanından geçer:

Şimdi elveda deme vakti.

Esip geçen yel gibi,

Gölgeler gibi..

Tutulmamış sözlere,

Agnes, erkek çocuklarının oynadığı sahada yürümektedir:

Sonsuza mühürlenmiş aşklara,

Agnes, okula doğru yönelir. Şarkının/şiirin sunumu, Agnes'in dış sesiyle devam eder:

Bileklerimi öpen çimenlere,

İçerisinde dersin yapıldığı bir sınıf, öznel açıyla dışarıdan gösterilir. Öğrenciler hep bir ağızdan tahtada yazılan şeyi okur:

Ve beni takip eden küçük adımlara,

Elveda deme vakti.

Agnes'in evinin avlusu gösterilir. Avluda sadece köpek vardır ve köpek,

44 Mija'nın yazdığı bu şiir, görsel içeriklerle paralel sunulmaya çalışılmıştır. Şiirin yer aldığı süre aralığı ise şu şekildedir: 02:12:25 - 02:15:29 
avluya birisi girmiş gibi kameraya doğru hareket eder ve sanki biri yanındaymış gibi, o "biri" nin üstüne atlamaya çalışır:

Karanlık çöküyor sanki.

Yeniden bir mum yanar mı?

Kimse ağlamasın dive,

Kamera otobüsün içerisinden dışarıyı seyreden "biri"sinin konumundadır. Çerçeveye otobüsle yarışmaya çalışan bir çocuk girer. Çocuk, otobüsle olan yarışında zafer kazanmış gibi ellerini havaya kaldırarak bir sokağa koşar ve kendisini izleyen o "biri"sine bakar:

Ve seni ne çok sevdiğimi bil dive,

Dua ediyorum.

Otobüs Agnes'in köyündeki durağa yanaşır. Durakta bekleyen iki kız öğrenci, otobüse biner ve otobüs uzaklaşır:

Sıcak bir yaz gününün ortasında uzun bir bekleyiş,

Babamın eski yüzüne benzeyen eski bir patika,

Yalnızlık bile yabani bir çiçek gibi ürkek,

Yüzünü çeviriyor.

Nasıl sevdim seni.

Mija'nın evinin bulunduğu sokakta sadece oyun oynayan çocuklar vardır:

Sessiz şarkını duyunca, nasıl da titredi kalbim.

Agnes'in intihar ettiği köprünün ortasında "biri"si vardır. Yoldan geçen bir kamyon, o "biri"sine korna çalar. Sola dönerek köprünün demirliklerine doğru yanaşır ve görüntüye Agnes girer. Agnes'in sırtı dönüktür ve demirliklere uzanır. "Biri"si köprünün altında akan nehri izleyen Agnes'in arkasındadır.

Dualarım seninle.

Kara nehri geçmeden önce,

Ruhum son nefesiyle,

Parlak bir günün hayalini görmeye başlıyorum.

Tekrar uyandığımda, ışıktan gözlerim kör.

Seni buluyorum.

Yanı başımda duruyorsun.

Nehrin görüntüsü tüm perdeyi kaplar. "Biri"si Agnes'e bakmaya devam etmektedir. Agnes arkasını döner ve o "biri"sine, yani Mija'ya ve bizlere bakar. Yüzünde gülmeye çalan bir ifade vardır; ancak çekingen ve ürkektir. Agnes'in bizlere dönük yüzünden, filmin başındaki nehrin görüntüsüne geçilir. Ancak görüntü bu sefer, karanlıktan aydınlığa açılmaz, aydınlıktan karanlığa gömülür ve nehrin 
bize getirdiği başka bir ceset de yoktur. Sadece suların gürleyerek aktığı ses vardır: "Mija'nın Şarkısı"nın sesi.

\section{Sonuç}

Çalışmanın temel sorunsalı olarak belirlenen sanatın doğasını anlayabilmemize yönelik filmin sunduğu olanaklar, Kantçı perspektif içerisinde anlamlı bir bütünlük sergiler. Çalışmanın bu bütünlüğe bağlı olarak ulaştığı bulguları özetlemek adına, filmin sonundan başlamamız faydalı olacaktır. Mija'nın bir "ödev" olarak sunduğu şiirin dizeleri, filmin bütününde yer alan olayların kendi üzerindeki etkilerinin ifadeleri olarak yer alır. Bu olayların kümesini oluşturan şey ise kötülügün her tarafa bulaşmasıdır. Mija, bu kötülüklere karşı şiir yazmaya çalışarak direnir. Bu bağlamda, onun bu çabasından türeyen şiirini, Kantçı anlamda iyinin sembolü olarak kabul edebiliriz. Ancak şiirine nüfuz eden olaylar ve durumlar sadece bunlardan ibaret değildir. Mija, dünyada var olma biçimiyle ve doğadaki güzele dair deneyimlerinden türeyen beğeni yargılarıyla da, kendisini güzel kılmış ve dünyayı güzel görmeye çalışmıştır. Onun için estetik bir temele dayanan bu varoluş biçimi, öylesine kendiliğinden ortaya çıkmaktadır ki, bu varoluş biçimine dair bir formül veya bilgisel bir çerçeve sunması mümkün değildir. Ancak bu yoksunluk, bir eksiklik değildir. Kantçı anlamda estetik hoşlanmanın veya duygunun dışavurumudur çünkü bu hoşlanmayla bir yarar sağlama anlamında hiçbir şey elde etmez; kavramlarla belirlenemeyecek bir ruh hâli içerisinde yaşamı deneyimlemeye çalışır. Bu deneyimin kendindeliği şiir yazma uğraşında sarsılmaya başlar çünkü hiç şiir yazmamıştır ve şiirin öğrenilebilir bir forma sahip olduğunu düşünmüştür. Ancak görecektir ki, böylesi bir bilgiye hiçbir zaman sahip olamayacaktır ve tıpkı varoluş biçimiyle doğadaki güzeli görmesi gibi, şiir de dolaysız bir biçimde ortaya çıkacaktır. Kantçı bağlamda, şiirin amaçsız amaca uygunluk olan doğasına yaklaşmaya başlamıştır. "Şiirin doğasına" yaklaşması ise, zaten varoluş biçimiyle onda var olan "doğanın şiirini" deneyimlemesinin tezahürü olarak ortaya çıkmıştır. Şiirindeki doğayı açık ettikçe, doğanın şiirine daha çok nüfuz etmiştir. Diğer bir deyişle, şiir aracılığıyla doğayla bütünleşerek yetiler arasındaki özgür oyundan türeyen "yaşama duygusunu" hissetmiştir.

Kavramları unutan ama belki de kavramların en güzelini sunan Mija, sadece şiir yazarak etik tavrını bizlere sunmaz. Aynı zamanda, etik bir eylemde de bulunur. Eylemleri de unutmaya başlayan Mija, etik bir karar alarak yapması gereken en yüce eylemi unutmaz. Kendisinin de dâhil olduğu bir kötülük evreninden bu yüce eylemle çıkar. Bu eylemden ve yazdığı şiirden sonra, Mija'yı bir daha görmeyiz. Ona ne olduğuna dair film bize cevap vermez ve zaten böylesi bir cevabın da pek önemi yoktur. Önemli olan, varoluş biçimiyle ve eylemleriyle ve belki de en önemlisi yazdığı şiirle, bir özne olan Mija'nın duygularımızı ve düşüncelerimizi sarsmasıdır. Öyleyse biz de, Mija'nın bir kaç dizesiyle bitirelim:

Şimdi elveda deme vakti.

Esip geçen yel gibi, 
Gölgeler gibi.

Tutulmamış sözlere,

Sonsuza mühürlenmiş aşklara,

Bileklerimi öpen çimenlere,

Ve beni takip eden küçük adımlara,

Elveda deme vakti.

\section{Kaynakça}

Adorno, W. T. (2005). Aşkınsallık Kavramı Üzerine. (M. Haydaroğlu, Çev.). Cogito-Sonsuzluğun Sınırında: Immanuel Kant, (41-42). 56-87.

Altuğ, T. (1995). Önyazı: Yargı ve Bilinç. Kant'ın Eleştirel Felsefesi içinde (Deleuze G., T. Altuğ Çev.) (9-25). İstanbul: Payel Yayınevi.

Altuğ, T. (2007). Kant Estetiği. İstanbul: Payel Yayınevi.

Baker, U. (2011). Beyin Ekran. İstanbul: Birikim Yayınları.

Cassirer, E. (1996). Kant'ın Yaşamı ve Öğretisi. (D. Özlem, Çev.). İstanbul: İnkılap Kitabevi.

Deleuze, G. (1995). Kant'ın Eleştirel Felsefesi. (T. Altuğ, Çev). İstanbul: Payel Yayınevi.

Deleuze, G. (2001). Cinema 1: The Movement-Image. (H. Tomlinson, B. Habberjam. Çev.). Minneapolis: University of Minnesota Press.

Deleuze, G. (2009). Issız Ada ve Diğer Metinler. (D. Lapoujade, Ed.). (F. Taylan ve H. Yücefer, Çev.). İstanbul: Bağlam Yayınclıı.

Deleuze, G. (2015). Kant Üzerine Dört Ders. (T. Kılıç, Çev.). İstanbul: Kabalcı Yayıncılık. Heimsoeth, H. (2016). Kant'ın Felsefesi. (T. Mengüşoğlu, Çev.). Ankara: Doğu Batı Yayınları.

Kant, I. (2007). Critique of Judgement. (J. C. Meredith, Çev.). New York: Oxford University Press.

Kant, I. (2016). Yargı Yetisinin Eleştirisi. (A. Yardımlı, Çev.). İstanbul: İdea Yayınevi.

Kant, I. (2017a). Arı Usun Eleştirisi. (A. Yardımlı, Çev.). İstanbul: İdea Yayınevi.

Kant, I. (2017b). Güzellik ve Yücelik Duyguları Üzerine Gözlemler. (A. Fethi, Çev.). İstanbul: Hil Yayın.

Kaygı, A. (2006). Sanat Olanla Olmayanın Sınırı. 8. Ulusal Sanat Sempozyumu içinde (1-22). Ankara: Hacettepe Üniversitesi Güzel Sanatlar Fakültesi Yayınları.

Kuehn, M. (2011). Immanuel Kant. (B. O. Doğan, Çev.). İstanbul: Türkiye İş Bankası Kültür Yayınları. 
Lee C. (2010). Shi (Film).

Neuman, W. L. (2012). Toplumsal Araştırma Yöntemleri Nitel ve Nicel Yaklaşımlar 1. (S. Özge, Çev.). İstanbul: Yayın Odası.

Öztürk, S. (2018). Sinema Felsefesine Giriş-Film Yapımı Felsefe. Ankara: Ütopya Yayınevi.

Savaş, H. (2020). Sinemada ve Edebiyatta Şiirin Yüzü. Ankara: Doruk Yayınları.

Schaper, E. (2005). Beğeni, Yücelik ve Deha: Doğa ve Sanat Estetiği. (A. Kaftan, Çev.). Cogito-Sonsuzluğun Sınırında: Immanuel Kant, (41-42). 154-182.

Tunalı, i. (2017). Estetik. İstanbul: Remzi Kitabevi.

Žižek, S. (2005). Kant ve Sade; Mükemmel İkili. (A. Kaftan, Çev.). Cogito-Sonsuzluğun Sınırında: Immanuel Kant, (41-42). 182-192. 